\title{
The Study of the Influence of Family Environment on the the Urban Social Integration of Floating Children in China
}

\author{
Shan $\mathrm{Wu}^{1} \&$ Xinde $\mathrm{Chen}^{1}$ \\ ${ }^{1}$ School of Management, Shanghai University of Engineering Science, Shanghai, China \\ Correspondence: Shan Wu, School of Management, Shanghai University of Engineering Science, Shanghai, ON., \\ Long Teng Road No.333, China. Tel: 86-139-1751-2674. E-mail: sea_windys@hotmail.com
}

Received: April 10, 2014 Accepted: April 23, 2014 Online Published: June 4, 2014

doi:10.5430/sass.v1n2p50 URL: http://dx.doi.org/10.5430/sass.v1n2p50

This work was supported by 2013 Special Inovation Program of Science Reseaech for SUES Postgraguate Student (No.13KY0340).

\begin{abstract}
In China, due to the development of urban transformation, a large number of rural surplus labor force have moved to those develop more rapidly urban areas. With the development of the times, the number of the floating children group has been multiplied, which has caused wide public concern in the society. How to make this special group quickly integrate into where they drifted into has become an urgent problem to be solved by those has accepted large quantity floating workers urban areas. Family environment is the first social place in contact with children's growth process. Promoting the family environment of floating families is helpful to the urban social integration of floating children. The paper will talk about the the important influence of family environment for the urban social integration of floating children by explain the family capital dilemma of the floating family. It has been found that the floating family can't creat a favorable family environment for floating children because of limited family capital, which has become the stumbling block of the development of the urban social integration of floating children.
\end{abstract}

Keywords: floating children, urban social integration, family environment, family capital

\section{Introduction}

In China, due to the development of urban transformation, a large number of rural surplus labor force have moved to those develop more rapidly urban areas. In the beginning, these laborer chosen to go out to work alone. With the development of the times, they migrated to the urban areas with their family members to earn a living. It should go without saying that the kids of these families, who are now the community known as the special groups called "floating children", has followed parents to move to the urban area, too. In 1998, Floating Children schooling Interim Measures has made a clear definition of floating children: the children refers to 6-14 years of age (or 7-15 years of age), who followed with their parents moved to the urban area more than six months to live temporarily with learning ability, and these children's household registration did not change correspondingly. After the phenomenon called "floating workers boom"(refers to a large number of rural surplus labor force have moved to those develop more rapidly urban areas) happened, the number of the floating children group is multiplied, which has caused wide public concern in the society. Research shows that most of the floating children come from the areas with backward economic growth, they follow their parents migrate to urban areas together and may live long where they moved to. According to China's Floating Population Development Report 2011, China's floating population has reached 221 million total. In some big cities, floating children accounted for $30 \% \sim 40 \%$ of the total number of children, which has become the immeasurable challenges to the urban area government. How to make this special group quickly integrate into where they drifted into has become an urgent problem to be solved by those has accepted large quantity floating workers urban areas.

Urban social integration needs urban area and floating people two-way cooperation to complete, but those floating workers who left one's native place are simply not strong enough. This requires the strength of urban area to help them get the opportunity and the rights to enjoy national harmony and prosperity development outcomes. Unlike 
their parents who work away from home, the place where the most of floating children can contact with the urban area life is in the school. That's why the experts who concerned about social integration of floating children in the urban area keen to discuss how to make a fair education for floating children. However, education is a process worked by the school education, social education and family education together(Liu. LH, \& Hu. W, 2009). Among these three parts, the family education is the most important. The influence of family environment on urban social integration of floating children can not be ignored. It plays a vital role to improve the current situation of floating children's families for their integrating into urban society. Ignoring the floating children's family environment dilemma, will bring immeasurable negative impact to the improvement of the overall quality of human capital in urban society. Therefore, ameliorating the family environment of the floating family has become the priority, unshirkable responsibility of those urban areas where have been accepted more and more floating workers and their children.

\section{The Influence of Family Environment on Children's Growth}

Family environment is the first social place in contact with children's growth process. The social effect accepted from family environment will influence on one's life. Especially the family education, which has some functions such as teaching basic life skills, developing good moral standard, forming noble moral sentiment, guiding individual ideal and interest, training to be adapted to the social and so on (Xu. ZY, 2007). The family characteristics in hierarchy and identity, and the economic income and educational status of parents have a major impact on children's behavior norm, psychological characteristics, value sense and lifestyle through daily life and activities(Zheng. HS, 2002).

Family environment is essential to children's growth. Parents should give their children a good living environment, at the same time improving their own quality to create a good cultural environment for children, treating the psychological problems of children correctly to guide them to grow up happy and good healthy. Psychological research shows that the more children by their parents in the family care guide more conducive to the formation and development of personality. The children with nice personality often have good development of learning and living.

As everyone knows, the family plays an extremely important role in forming children's good moral behavior. Although parents think psychologically that moral education of children in family education is the most important matter, in fact, parents mostly concern about the children's learning, scores and other intellectual issues. In a manner of speaking on this issue, there is a serious disconnect between knowledge and behavior of parents. Too many restrictions on children may cause problems that children arise antagonistic mentality, learn as a burden, evade study, so far as to only attach importance to achievements and have unsound personality.

\section{The Emergence of Floating Family}

In the past, only some male members of rural families moved to urban areas to earn money for their other family members, such as their wives,children and parents, who still lived in rural areas. When the female laborers find that the money their husbands and brothers earned in urban areas was many times than in rural areas, they began to have the idea about following the male laborers move to urban areas. But due to the high living cost in urban areas, the floating families with all family members was less common in urban areas.

With the development of the cities, those floating workers who left their children behind in their villages to be looked after (often not very attentively) by grandparents or other relatives, gradually recognized that knowledge could create wealth and expected to send their children to university. But because of the urban and rural areas two system in China, the quality of rural education is worse than urban's. In order to provide a better education for their children, the floating parents decided to take children into urban areas with them together.

Nowadays, the number of floating children continue to rise. This phenomenon not only reflects the importance of cultural education in the comprehension of floating workers from rural areas, but also has changed the development of the structure of Chinese society.

\section{The Impact of The Capital Dilemma of The Floating Family}

In China, before the 1984s, government severely restricted farmer-workers from moving to urban areas to according to the principle of household registration system. Then, in 1984s, the country removed limitations for a small portion of farmer-workers. In 1992s, the country established series of related floating laborers policy to encourage farmers to work in the cities. In 2003s, the State Council promulgated The Notice on Promoting Employment Management and 
Services for Farmer-workers in The Cities. This notice not only includes the security related to labor rights of migrant workers, but also stress the improvement of the living conditions of them, the equal education for migrant children, and other related matters. However, it's hard to be changed that floating families are still in weak strata of the cities, which has been influenced on the urban social integration of floating children.

French sociologist Pierre Bourdieu in his article namely Forms of Capital divided the family capital into three forms: economic capital, cultural capital and social capital(Bao. YM, 1997). Applying this theory, the Sociology of Education concluded that there is a huge difference in family capital of children of different family backgrounds. Some related study found that family capital doesn't directly impact on children's personality, attitude, behavior and cognitive ability, but in the methods of family education for children to realize the role of early socialization. A survey shows that since 1978, the influence of family background factors and institutional factors on the individual educational opportunities significantly increased. The influence from social capital, cultural capital and economic capital and other background factors of family on children's educational opportunities have rocketed from $9.9 \%$ in the early 1980 s to $17.9 \%$ in the 1990s. Recently, this influence is still rising (Dan. SB, 2008).

\subsection{Family Economic Capital}

Family economic capital refers to the resources which is invested in children's education by parents in the form of substance(Cang. C, 2008). The capital is the most important capital in the family, but also by the dual effects of family cultural and social capital. The higher the cultural capital is, working ability will increase accordingly; relatively speaking, family income will be constrainted by working skills and knowledge. The more communicative wide range of family members is, work opportunities will be improved proportionately; otherwise one man will be bound in a "subculture circle", and the income of family members is limited by the level of family social capital.

1) Parental occupation

The most of floating families come from rural areas, though there are some typical rags to riches. Due to the cultural level limit, parents are mostly engaged in "dirty, tired, and dangerous" types of work in this society. Since the rising crime rate caused by outsiders who come from outside place, and the deeply ingrained ideas between urban and rural areas, the floating workers with the lower working ability could not be fully trusted by the local people. As a result, the floating parents can hardly engaged in decent occupation. Even some parents let their children give up learning and the rest of the time to complete the work they haven't finished. These reason made floating children realize the hardships of life earlier than urban children as they has awared of the gap between urban children and themselves.

\section{2) Parental income}

In recent years, floating workers income is constantly increasing, but the income gap between urban and rural areas is still obvious. The income differential has attracted countless number of floating workers to leave home, came to the cities to work hard to earn a living. However, in order to get the better income, they must get ready for bearing the high consumption of the urban areas. The escalating prices cause the floating families life more pinched in urban areas. The relative higher income in the urban areas life compared by in the rural areas cannot withstand a single blow. Although illiteracy rate of floating workers has been decreased year by year, the cultural level is still at a relatively low level of civilization. That's why the floating workers can only engage in simple labor occupation. Due to weak illegal awareness, floating workers often suffer wage arrears or fraud. Meager and unstable income has become all the economic capital accumulation source of floating families. For the reason, the migrant laborers are busy to earn money to support their families, which caused floating parents have less time to take care of children. The effective time of parent-child communication greatly reduced, so that floating children in the bustling urban areas feel more lonely.

\section{3) Living environment}

Because of the limited household income, the most of floating families choose rent to live. Rental housings are mostly in the urban fringe so that the floating families there have formed a narrow social circle of life with the surrounding neighbors who live in a similar life. Although some floating families conditionally admit to a good residential district, the families members can't maintain good neighborly relations with other residents within the district, because of their limited literacy and the local residents rejection of them. The floating families are living in urban areas, but they can't be integrated into urban areas life. Although those floating children's standard of living has improved, the concept of "Better city, better life" can't let them have the sense of belonging to the urban areas.

4) Floating frequency

Due to the unstable occupations, irregular rent prices and other objective reasons, these floating families have several 
times to move helplessly, which became a veritable "mobile home" in urban areas. The reassuring and comfortable living environment can help a growing kid develop a stable individual psychological qualities and behavior. However, floating children forced to follow their parents repeatedly replace the growth environment. Every change about neighborhood, living environment, school life, teachers and students will prevent children from forming a stable relationship between groups and maintaining a social support network.

To sum up, in the economic capital is not sufficient families, floating children's living and learning environment is worrisome. They don't have stable family environment because of the poor living environment and moving frequently. That's made the floating children who is lack of confidence don't dare to establish emotion with surrounding neighborhoods, classmates and teachers.

\subsection{Family Cultural Capital}

Bourdieu pointed out that the way of family influence on children is not only the economic income, the more important is the various forms of cultural capital (David. S, 2006). The cultural capital of family is the specific social resources which the family members accumulate through mutual communication and practice, such as cultural knowledge, cultural skills and cultural enrichment and so on(Cang. C, 2011). Family cultural capital depends on parents' educational level and quality cultivation. Parents with higher education not only will use more correct concept of education to teach their children, but also will pay more attention to create a good family atmosphere for children. However, a survey found that floating children's parents show a strong sense of responsibility for their children's education, the attention to the education mode, fully aware of the importance of parental involvement education; because of the limitation of objective conditions, floating parents can not achieve a good education for their children, which affect the quality of family education (Niu. LX, \& Zhou. YK, 2011). The weak cultural capital of floating families makes children be lack of the cultural knowledge and accomplishment. This will obstruct the development of the urban social integration of floating children.

\section{1) Educational degree}

Parental educational degree has a profound impact on the urban social integration of floating children. One study found, the illiteracy rate of floating workers from the rural areas is low, but their educational degree is mostly junior high school level, some people even have not graduated from primary schools. Although floating family parents realize the importance of learning and require children to study hard, but they can't give effective coaching to their children when children is reviewing the lessons at home because of the their restricted educational degree. In daily life, the floating parents may scold and beat their children who have done something wrong or get a poor score. That parents ignore the self-esteem and character of kids when they want their children to prosper, to matter, may lead children to become rebellious and stubborn. In severe cases, punishment and domestic violence may make the child plant seeds of criminal psychology in their minds.

2) Educational conception

The parents in China always want their kids to complete their unfinished ideal. The floating people who come from rural areas have awared of the importance of education deeply. Because of the better educational conditions in cities, more and more floating children have been taken to the urban where heir parents live in from rural homes. Compared with the people in cities, the social status and living conditions of floating workers are poor. They are dissatisfied with the status quo but can not change it. That's the reason why they desperately want their children to receive a good education to became the part of the prosperous urban areas. Then the floating parents with this conception that make money is just for children's have been increasing their children's learning load. The children would be punished if they don't study well, which may cause children have reverse psychology.

\section{3) Educational expectation}

Nearly all the parents of the whole world burden their kids with nosmall expectations, no exception the migrant parents. According to one survey data, among of the floating families in Changzhou, China, fifty-two percent of parents hope their children can receive higher education to obtain high degree; twenty-eight percent of parents want their children to have a strong comprehensive ability to be adapt to the society; twenty percent of parents want children to have proficiency in a particular line (Wang. Y, 2013). However, there are few floating children can admitted to universities and complete the wish of the parents. What the unfavorable factors they have? First is that floating children have no place to study attentively and no time to communicate with parents; second, being limited by the household registration system, after floating children received nine years of compulsory education in the urban areas, only a few could continue to stay in the local schools. It's hard to realize the educational expectation of floating parents for their children. 


\section{4) Educational mode}

The family educational mode is divided into democratic type, doting type, indulgent type, authoritarian type, indifference type, etc. Among them, the most ideal type is democratic type, which can make children be socialized earlier and better (Zhao. J, 2003). But, in fact, authoritarian type is more common in floating families. Floating workers often be burdened with hectic works, so they have less time and energy to help children with their homework. Once the children did not meet their expectations, some of them may beat and scold children to vent anxiety and anger heart. This behavior will not only cause children's rebellious, also will make the children more and more afraid of learning and become have no confidence. Sometimes floating parents give money as a reward when children get a nice grade, which may cause distorted values of kids.

As the cultural and social reproduction scholars represented by Bourdieu pointed out, "After eliminating the influence of the factors of economic position and social origin, the students, who come from the families with better cultural cultivation, not only have higher academic success rate, but also show different type of cultural consumption and cultural expression compared with the students come from other family background (Pierre Bourdieu, \& Wacquant, 1998). " The adequate family cultural capital can guide the children to grow up healthy. On the contrary, the thin capital of family cultural, which may brings a bad influence on the training mode of personal morality, connotation of culture, standardized behaviors of floating children, not only can't help the children integrate into urban life, but also may make the children fall into a wrong way.

\subsection{Family Social Capital}

Family social capital refers to the interpersonal relation networks based on trust, norms, institutions, and responsibilities between family members or with others outsiders, is a kind of social resources which has an important impact on the growth of children(Cang. C, 2008), such as the communication between children and parents, the relationship between parents and teachers, neighbors and friends. It has been found that the more social capital a family have, child may obtain more opportunities and resources. However, due to some subjective and objective factors, the floating family often be a shortage of social capital - parents has little times in touch with their children even though they live together, communicating with those who are similar to their position, not to mention the regular contact with teachers. This is not conducive to the healthy growth and family education as well as not good for the urban social integration of the floating children.

\section{1) Family atmosphere}

Couplehood and parenthood is important in family. The quality of these tow relationships can affect the family atmosphere of a home. The better these tow relationships are, the more warm and cozy family atmosphere is, which more favorably affect a child's growth. But the data indicate that the overall status of floating family atmosphere is not satisfactory. In the survey about the communication frequency between parents and children, only thirty percent of the floating children often chat with parents; twenty percent of the floating families even almost have no parent-child communication; the half of the floating children occasionally talk with their parents. The investigation on the quality of parenthood shows that, the thirty percent of the floating children think their parents know about them a little, half children think parents understand their own, the remaining even unknown whether parents understand them or not(Wang. YJ, \& Gao. Y, 2010). The deletion of affective interaction leads the floating children have adverse cognition about themselves, the other people and the surroundings they live in.

2) Social relationships

Because the cognition of floating children about the urban areas and the residents in cities is a habitual prejudice to a large extent, not formed by the experience of individuals (Xiong. YH, 2009), in the floating children's cognition, it prodigiously depends on parents minds and behaviors that whether they want to remain in or be willing to integrate into the urban areas(Wang. YJ, \& Liu. HJ, 2008). However, the personal connections of the floating people is not satisfied for some objective reasons. Even so, some floating workers reluctant to deal with urban residents, some even refuse the help from the community they live in, while blame the community don't give any help for them. All of these will prevent the floating children from being a part of the urban area.

\section{3) Native dialect}

As a place marker, native dialect is an obstacle of the urban social integration of floating children. When some floating children talk with others, their heavy accent can't be understand by teachers and classmates. If that the accent is laughed by classmates happens, the floating children would feel self-abased. And then, they who speak mandarin not very well may be afraid to speak in public. At home, the parents mostly use native dialect to communicate with their children who have less opportunity to master mandarin. To build a bridge of communication 
with the urban areas for them, to help floating children master mandarin should be planed in the task of the urban social integration.

In a word, family social capital plays a vital role in the urban social integration of floating children. The depression of the parenthood, the poor social interaction and the heavy accent may prevent the floating children from having a sense of belonging to the cities they live in. In addition, the family social capital can also play a role in other forms, for example, the floating parents must have useful interpersonal relationship if they want to send their children to a good school. To be sure, without family social capital, the economic and cultural capital of family can not work on them own.

\section{Conclusion}

Parents' attitude can colour the way the floating children think and feel about all sorts of daily issues. Family environment is highly important in promoting the urban social integration of floating children. There are several floating families from the rural areas, which have get rid of the misery of life, can provide children with good family environment, education and social platform. But there are more floating families can't create a steady family environment because of their finite family capital, even so they have been struggled to earn money for their children.

In order to make children's life better than themselves, the most of floating family parents work hard to earn more money and repeatedly ask children to study diligently. But they ignore the children's own feelings and forget the things which is most needed in the child's stage: care and love. In a family with adequate wealth, if the parents are too busy to have time to give children enough care and love, the children may can't grow up healthy. In contrast, even without good economic foundation, higher degree of education and extensive personal connections, the parents in the floating family can also create a harmonious family atmosphere for children by helping the children establish the correct faith in life and admirable character behavior. Even the floating children did not get excellent achievement, but also can effectively encourage them to expedite the completion of the integration of the urban society.

In summary, how to help these floating family parents to creat a comfortable environment for children in a right way has been a pressing issue for Chinese government. The family environment quality is not only limited to objective factors of economic, cultural, social intercourse, but also should be promoted by changing the subjective factor of parents. A good personality can be shaped by a good family environment, which is good for floating children to integrate into the urban life.

\section{References}

Bao, Y. M. (1997). Cultural capital and social alchemy - interview with Pierre Bourdieu. Shanghai, China: Shanghai People's Publishing House.

Cang, C. (2008). A study of the effect of family capital on children's readiness for school. Early Childhood Education (Educational Science), 09, 42-46.

David Swatz. (2006). Culture and power: Bourdieu's sociology (Tao. DF, translation). Shanghai, China: Shanghai Translation Publishing House.

Liu, L. H., \& Hu, W. (2009). The reflection of constructing the social support system for the family education of migrant children. Journal of the Party School of C.P.C. Qingdao Municipal Committee Qingdao Administrative College, 02, 44-48.

Niu, L. X., \& Zhou, Y. K. (2011). The effect of family capital on migrant children's family education. Journal of Southwest Agricultural University (Social Sciences Edition), 07, 163-168.

Pierre Bourdieu, \& Wacquant. (1998). Practice and reflection -- reflection on the sociological direction. Beijing, China: Central Chinese Compilation\& Translation Press.

Shan, S. B. (2008). Vigilance the affect of "family capital" on social justice. China Economic Times, 09, 63.

Wang, Y. (2013). Investigation and analysis of migrant children's family education. The New Curriculum, 04.

Wang, Y. J., \& Gao, Y. (2010). Social intergration between the migrant peasants'children and urban citizens. Beijing, China: Social Sciences Academic Press.

Wang, Y. J., \& Liu, H. J. (2008). Family background and the willness of staying in the cities of the migrant children. 
South China Population, 04, 38-44.

Xiong, Y. H. (2009). Urbanization children: the cognitive awareness and identity of the children of migrant workers in urban and rural areas. China Rural Survey, 02, 2-11 \& 45.

$\mathrm{Xu}, \mathrm{Z}$. Y. (2007). The report of the effect of family education on students'learning. 21st Century Education Ideological Literature, 01, 4-9.

Zhao, J. (2003). The qualitative study on the parenting style of floating population family. Youth Studies, 08, 15-22.

Zheng, H. S. (2002). The new concept of sociology. Beijing, China: China Renmin University Press. 